\title{
Integrity Pact in Percut Sei Tuan Subdistrict Office, Deli Serdang District
}

\author{
Indra Muda ${ }^{1}$, Rosmala Dewi ${ }^{2}$, Effiati Juliana Hasibuan ${ }^{3}$, Nina Siti Salmaniah ${ }^{4}$, \\ \{indramudahts@gmail.com ${ }^{1}$,rosmala@staff.uma.ac.id ${ }^{2}$, effiatihsb@yahoo.co.id ${ }^{3}$, \\ ninahalimsrg@gmail.com ${ }^{4}$ \} \\ Department of Public Administration, Faculty of Social and Political Sciences \\ Universitas Medan Area Medan, Indonesia ${ }^{1,2,3,4}$
}

\begin{abstract}
Integrity Pact is a form of a statement to oneself by a government employee regarding the commitment to carry out all duties, functions, responsibilities, authority, and roles under statutory regulations, and the ability not to conduct KKN. The problem is how the efforts of Percut Sei Tuan Subdistrict Government to implement the Integrity Pact, what are the inhibiting factors to carry out the Integrity Pact. To obtain the data, it conducted by using observations and in-depth interviews with respondents. To carry out these activities the researchers went to the respondents who were related to the implementation of the integrity pact. According to the study, the implementation of the integrity pact in the PercutSei Tuan Subdistrict Office was done by growing and developing the State Civil apparatuses' awareness of its position as a state servant and public servant guided by the integrity pact and understood the points contained therein. In this way, in the self of State Civil Apparatuses' grows ashamed when being late entering the office and quickly leaving the office, feeling ashamed to receive money or goods from the services provided to the community. With such a State Civil Apparatuses' attitude, it facilitates the supervisory task of the leadership to its subordinates. The inhibiting factor in carrying out the integrity pact is, there is still a negative perception of some people about the State Civil Apparatuses' services that must be accompanied by giving an amount of money if the business wants to be finished quickly. On the other hand, there is still a citizen who does not comply with population data, including the problem of domicile conditions.
\end{abstract}

Keywords: Integrity Pact; Supervisory Function; Deli Serdang District

\section{Introduction}

Integrity Pact is a form of a statement to oneself by a government employee regarding the commitment to carry out all duties, functions, responsibilities, authority, and roles under statutory regulations, and the ability not to conduct KKN. The implementation of the Integrity Pact within the State Ministries/Institutions and Local Governments uses a basic reference that is the State Minister Regulation of the utilization on State Apparatus and Bureaucracy Reform Number 49 of 2011 concerning General Guidelines for the Integrity Pact in the Environment of State Ministries/Institutions and Regional Governments [1]. Based on this Ministerial Regulation, it means that every leader of the Ministry/Institution, Local Government, officials, and government employees must obey them. 
To obtain the validity of the Integrity Pact, each employee is required to make a statement, then sign it. The items contained in the Integrity Pact consist of, (1) playing a proactive role in efforts to prevent and eradicate Corruption, Collusion and Nepotism and not to involve themselves in disgraceful acts, (2) do not ask for or accept gifts directly or indirectly in the form of bribes, gifts, assistance or other forms that are not in accordance with applicable regulations, (3) be transparent, honest, objective and accountable in carrying out the task, (4) Avoiding conflicts of interest in carrying out the task, (5) Give examples and compliance with laws and regulations in carrying out tasks, especially to employees who are under my supervision and fellow employees in my work environment consistently (6) Will submit information on integrity deviations at the agency/work unit and also maintain the confidentiality of witnesses for violations of the reported regulations, and (7) if I violate the above, I am ready to face the consequences.

The research objective is to examine the efforts of Percut Sei Tuan Subdistrict Government to implement the Integrity Pact, to examine what the inhibiting factors of implementing the Integrity Pact in the Percut Sei Tuan Subdistrict Office. The State Minister Regulation of the utilization on State Apparatus and Bureaucracy Reform Number 49 of 2011 concerning General Guidelines for the Integrity Pact in the Environment of State Ministries/Institutions and Regional Governments stated, "Integrity Pact is a statement or promise to the self about the commitment to carry out all duties, functions, responsibilities, authority, and roles in accordance with statutory regulations, and the ability not to commit corruption, collusion and nepotism (KKN) [2].

\section{Research Methods}

To obtain the data, it used a qualitative historical approach in which the research process is carried out with a reasonable or natural background, the process forms a cycle that focuses on understanding the object under study using the research field and the farm of reference by the research team. This study does not use the term population. The sampling technique used by researchers is a purposive sample. According to Sugiyono [3]. A purposive sample is a sampling technique with certain considerations.

According to Arikunto [4], purposive sample selection in the study will be guided by the following conditions that must be met: (1) conducting samples must be based on certain characteristics which are the main characteristics of the population principal, (2) subjects which taken as samples really are the subjects that contain the most features found in the population (key subjected), and (3) determination of population characteristics will be done carefully in the preliminary study.

According to Suyanto [5], "the research mechanism in the research informants includes several kinds, there are key informants, main informants, and additional informants". Burhan Bungin [6] argues: the rolling of sample selection through snowball sampling techniques, both for informant samples and social situations, will eventually arrive at a boundary where no variation in information is found (information saturation occurs). At this time the selection of new samples is no longer needed, in other words, the activity of collecting data or information in the field is considered to be over. In the process of collecting research data the following research techniques are used: (1) direct observation, that is observations made to determine the condition of objects regarding various supervisory activities in the framework of the integrity pact, (2) interviews that is direct question and answer conducted with informants and people related to the problems being investigated. The form of interview used is in-depth interviews. In-depth interviews are the way to collect data by face to face with informants, to get a 
complete description of the subject matter being investigated, which is carried out carefully and repeatedly, and (3) literature study to obtain relevant secondary data to explain the condition of the research subject.

The mechanism of research data analysis is carried out through three steps, there are data reduction, data display, and conclusion/verification, and the details are as follows: (1) data reduction, which is choosing data that is relevant and meaningful, focuses the data that leads to problem-solving, discovery, meaning or to answer research questions. Then simplify and arrange systematically and describe important things about the findings and their meaning, (2) data display, which can be in the form of writing or words, pictures, graphs, and tables. The aim is to combine information so that it can describe the situation that occurs, and (3) conclusion/verification, which is carried out during the research mechanism takes place as it is the mechanism of data reduction, after the data is collected and sufficiently adequate then the temporary conclusions are drawn and after the data is complete the conclusions are drawn.

\section{Result and discussion}

The Percut Sei Tuan Subdistrict Office is located on Jalan Besar Tembung No. 22, which is on the Medan-Batang Kuis track. With the strategic position of the office that be passed by vehicles from various directions, so that people who deal with the Head of Percut Sei Tuan Subdistrict office can easily reach it both by public vehicles and by personal vehicles of motorbikes and cars. As a government service center in the sub-district area, the Percut Sei Tuan Subdistrict Office is classified as one of the oldest sub-district offices in the Deli Serdang District.

The implementation of integrity pact in the Percut Sei Tuan Subdistrict Office is guided by the State Minister Regulation of the utilization on State Apparatus and Bureaucracy Reform Number 49 of 2011 concerning General Guidelines for the Integrity Pact in the Environment of State Ministries/Institutions and Regional Governments. In its application, it is certainly uniform for all government institutions throughout Indonesia. With the issuance of the Ministerial Regulation (Permen), the first thing done by the Camat or the head of Percut Sei Tuan Subdistrict is to disseminate it to all State Civil Apparatuses (ASN) in the Percut Sei Tuan Subdistrict Office, so that they can understand the points contained therein.

Manullang [7] argues, there are several ways to gather facts, namely: (1) personal review, (2) interview or verbal, (3) written report, and (4) reports and supervision of special matters. According to an interview with the Head of Percut Sei Tuan Sub-district (Camat), 2017-2019 period, Timur Tumanggor stated:

"The concept of integrity pact was born related to the government's efforts to empower ASN performance maximally. To obtain the maximum performance, according to its position, ASN must obey various rules and keep the prohibitions set. In this case, the ASN must distance itself from the KKN actions. Based on the mandate of the Minister of the Interior, the Percut Sei Tuan Sub-district government certainly supports by complying with various rules and abandoning restrictions, including the application of discipline in and out of the office"

For the hour's rules of entry and leave of ASN in the Percut Sei Tuan Sub-district, it made the attendance that must be filled every day by ASN. This attendance is filled twice a day, at the time of entering the office and at the time of leaving the office. The absence of attendance helps a lot of enforcement of discipline in and out of the ASN office. According to an interview with the Secretary of Percut Sei Tuan Sub-district, Harles stated: 
"In the context of upholding discipline entry and leave of the office, each ASN is required to sign attendance twice in one workday that is, at 00.08 WIB is entry attendance and 16.00 WIB is leaving work attendance. This attendance is placed in front of the picket table so that it will be discovered by anyone picking the ASN who signs the attendance late. Furthermore, the picket will report it to the Sub-district Head or Secretary. As time goes by, ASNs are generally able to comply with the hours of entering and leaving the office, because it can foster embarrassment for ASN if it is too late to enter and leave the office quickly"

Related to the explanation delivered by Sub-district Secretary of Percut Sei Tuan Subdistrict, according to the research team's observation it has relevance. That said, some of the ASN before the hour of work came at 00.08 WIB they had arrived at the office while fixing things that were important to provide services to the community. Based on the observation of the research team, this condition certainly did not just happen but had already developed a system or work process so that each ASN already knew what were the jobs.

Every working day at $12.00-13.300 \mathrm{WIB}$, is the time of rest. Information about this is written on a service board that is easy for the public to see. With this rule, the community can find out the right time to take care of their needs with the Percut Sei Tuan Subdistrict Office. Muslims who want to pray the $d z u h u r$, can be resting time at the Pray room located behind the Percut Sei Tuan Subdistrict Office. In several observations made by the team in the Percut Sei Tuan Sub-district Office, ASN was used by the mosque for many dzuhur prays, not even by ASN but also by the people who dealt with the Percut Sei Tuan Subdistrict Office.

Related to the service system that is implemented in the Percut Sei Tuan Subdistrict Office, it is done by making 4 (four) service counters. At each service counter, one person is guarded. So, citizens who want to deal with the service of the Percut Sei Tuan Subdistrict Office are required to take a queue number at the place provided and wait for a call from the ASN who is on duty at the counter according to their respective queue numbers. According to an interview the research team conducted with the Head of the Village Development Section, Dinilah Arifah stated:

"every day there are 4 service counters available at the Percut Sei Tuan Subdistrict Office. When many people are dealing, then the four service counters will be functioned, while when empty only 2 or 3 service counters will function. With these service counters, the people who deal only with the ticket window clerk, then the ticket clerk will forward it to officials or personnel who are competent with the type of community affairs"

Based on observations made by the research team for approximately 2 hours in 3 working days at the Percut Sei Tuan Subdistrict Office, the service system through the service counters can create comfort and order for the community. In front of the service counter, there are 35 waiting chairs. In this waiting room, it is equipped with a cooling room from several fans and is equipped with a 32 -inch television set. With the availability of this television set, it can reduce the community's boredom while watching entertainment on the television show. So, if there is a shortage of files in community affairs, then the ticket window will be delivered directly to the community members. According to interviews the research team conducted with the Head of Public and Civil Service Subdivision, Asmaningsih stated:

"in certain cases, there are community affairs that need to get legality from the Deli Serdang District Office such as licensing, distribution of assistance, and others. For managing such needs, not every day there is personnel who will deliver it to Lubuk Pakam. Sometimes it is done 1 time in 2 days. However, if the community's needs are urgent, they 
can deal with the boss's government or directly deal with the supervisor's agency after obtaining approval from the Percut Sei Tuan Subdistrict Office"

Based on the observation of the research team, in general, the service system applied by the Percut Sei Tuan Subdistrict Office is good. In terms of the management of community needs, such as how to make a National Identity Card (KTP), making a Family Card (KK), completeness of making land certificates and others, the required completeness and the Standard Operating Procedures (SOP) have been announced. With this clarity, the community can prepare it before making arrangements so that it does not require much more time for management. Matondang [8], then the environment of government agencies also often guide its employees under the policies of the relevant agencies. Moekijat [9] argues, "Employee coaching is an attempt to increase skills, through the training needed to carry out good duties". According to an interview the research team conducted with 3 community members who were dealing with the Percut Sei Tuan Subdistrict Office, on behalf of Taufik Wal-Hidayat, they thought that:

"The public service system at the Percut Sei Tuan Subdistrict Office is generally good. The ASNs who are tasked with being friendly, clear procedural management and if the community lacks the intended procedural understanding, ASN is ready to explain so that it can be understood. The location of the Camat Office on the strategic Medan-Batangkuis highway is very helpful for the public to reach it easily because it is passed by public transportation from various directions"

Based on the observation of the research team, the ASNs in working under the procedures according to their respective duties. Within the personnel, there is an impression that they will feel embarrassment if doing outside the procedural in force, both in providing public services and concerning discipline the entry and leave of the office. The provisions contained in the Integrity Pact are rules in personnel in carrying out their duties so that leaders no longer feel inconvenienced to carry out supervisory duties, because the supervision system has been built up within ASN.

Regarding the inhibiting factors in the implementation of the integrity pact nothing stands out, it is just that in certain cases there is a false public perception of the actual conditions. Cases that have erupted in the Percut Sei Tuan sub-district area in the form of several matters must be supported by giving money to certain individuals or bribes. After the research team investigated, it turned out that the real cause was not like information circulating from one citizen to another. According to an interview the research team did with Kasi. Government, Fate of Solichin, stated:

"Information has been circulating in the community which states that related to matters with the Head of Percut Sei Tuan Subdistrict Office, it requires high costs and giving a certain amount of money for certain matters. In reality, it turns out there are brokers who sell the names of certain elements and then spread to other cities and then inform them by word of mouth. Another case in the form of a citizen who asked ASN for help in bringing the documents he needed received authorization from the superiors in the Deli Serdang District's Office and gave some money for transportation, then the distribution of transportation money was spread into illegal levies"

Therefore, citizens who want to deal with the Percut Sei Tuan Subdistrict Office should take the set of procedures that have been determined and there will be no fees beyond the stipulated provisions. Brokers who offer can take care of a variety of matters including the 
creation of a National Identity Card (KTP), Family Card (KK), and Certificate of Land Ownership to be ignored because they will ask for higher fees according to the stipulated rules.

Regarding population administration in the Percut Sei Tuan sub-district has not proceeded properly, there are still many citizens who do not obey it. In the Percut Sei Tuan Sub-district Office and also in several villages' banners that read, "Mandatory reporting" for the citizen who lives 3 times 24 hours have been made. But in reality, there are still many citizens even who have lived in the Percut Sei Tuan Sub-district for years, still using the Medan City resident card or other areas. This is certainly related to the boundaries of the city of Medan directly bordering the Percut Sei Tuan District. Not infrequently the citizen of Percut Sei Tuan sub-district work and do work activities in the Medan city. They leave in the morning and return home in the afternoon, some even go home once a week. This attitude of the community is not uncommon for the local government of Percut Sei Tuan Sub-district. To straighten out the negative information circulating in the community, ASN in the Percut Sei Tuan Sub-district Office continues to build a positive image by providing the best service to the community under the instructions given by the Camat Head of the Sub-district and the applicable provisions.

\section{Conclusions}

The conclusions are drawn as follows: (1) the implementation of the integrity pact is carried out by growing and developing ASN or State Civil Apparatuses awareness of its position as a state servant and public servants who are guided by the integrity pact and understand the points contained therein, and (2) the inhibiting factor in carrying out the integrity pact is, there is still a negative perception of some people about the State Civil Apparatuses' services that must be accompanied by giving an amount of money if the business wants to be finished quickly. On the other hand, there is still a citizen who does not comply with population data, including the problem of domicile conditions. Some suggestions are the following (1) in implementing the various interests related to PercutSei Tuan Sub-district Office services, the community should do it directly and not use the services of brokers, because it is not uncommon that the fees requested by brokers are far greater than the actual costs, and (2) citizen who lives in PercutSei Tuan Sub-district in order to have a population identity according to their domicile. Citizens who violate the population constitute, including a place of domicile that is not under the identity of the population, to be subject to strict sanctions.

\section{References}

[1] Sekretaris Negara RI (Secretary of Republic of Indonesia, 2017, UUD 1945 (Amendment IV).

[2] The State Minister Regulation of the utilization on State Apparatus and Bureaucracy Reform Number 49 of 2011 concerning General Guidelines for the Integrity Pact in the Environment of State Ministries / Institutions and Regional Governments.

[3] Sugiyono. Metode Penelitian Kuantitatif, Kualitatif dan R\&D, Alfabeta, Bandung, 2009.

[4] Arikunto, Suharsimi. Prosedur Penelitian Suatu Pendekatan Praktik, PT. Rineka Cipta, Jakarta, 2010.

[5] Suyanto, Bagong. Metode Penelitian Sosial, Kencana Prenada Media Group, Jakarta, 2005.

[6] Burhan, Bungin, Analisis Data Penelitian Kualitatif, PT. Raja Grafindo Persada, Jakarta, 2003 
[7] Manullang, M.Dasar-dasar Manajemen, Ghalia Indonesia, Jakarta, 2011.

[8] Matondang, Armansyah., (2015). Pembinaan Aparatur Pemerintah dalam Pelaksanaan Tugas di Bagian Umum Sekretariatan Kantor Bunati. .IPPIJMA: .Jurnal Ilmu Pemerintahan dan Sosial Politik UMA(Journal of Governance and Political Social UMA, 3 (2): 160-174.

[9] Moekijat, Manajemen Personalia, Alumni Bandung, 2007 